\title{
Wojciech Jarczewski
}

Instytut Geografii i Gospodarki Przestrzennej

Uniwersytet Jagielloński

\section{Duch przedsiębiorczości w proinwestycyjnych działaniach władz lokalnych}

Pozyskiwanie nowych inwestorów dla gmin nie należy do bezpośrednich obowiązków władz lokalnych i jest jednym z przejawów wskazywanej często (m.in. Osborne, Gaebler 1995; Swianiewicz $i$ in. 2004) zmiany filozofii kierowania gmina - od administrowania (local government) do rządzenia (local governance). Czaso- i kosztochłonne kompleksowe działania proinwestycyjne mogą być wdrażane tylko w tych gminach, w których żywy jest duch przedsiębiorczości wśród władz lokalnych. G. Gorzelak (1998) wskazał, że jakość przywództwa na szczeblu lokalnym jest najważniejszym endogenicznym czynnikiem sukcesu lokalnego, w tym pozyskiwania nowych inwestorów.

W celu zbadania znaczenia i zróżnicowania postaw władz lokalnych w działaniach proinwestycyjnych, w samorządach lokalnych przeprowadzono analizę porównawczą dla czternastu wybranych w Polsce gmin (tab. 1). W badanej grupie znalazły się dwie metropolie: Kraków i Wrocław, oraz 12 małych i średnich miast i gmin wiejskich. W 9 badanych gminach po $1990 \mathrm{r}$. lokowali się nowi, średni i duzi inwestorzy. Te gminy, nazwane w pracy gminami proinwestycyjnymi, podzielono na dwie grupy. Do pierwszej - doświadczonych gmin proinwestycyjnych - zaliczono te, w których inwestorzy lokowali się już w latach 90. XX w. Do drugiej - nowych gmin proinwestycyjnych - włączono gminy, do których inwestorzy zaczęli napływać głównie po 2000 r. Przebadano także 3 gminy, które nie pozyskały istotnych nowych inwestorów po $1990 \mathrm{r}$. W pracy nazwano je gminami nieinwestycyjnymi.

Analizowano działania proinwestycyjne podejmowane od 1990 r. oraz ich efekty - napływ nowych inwestorów. Do badania włączono gminy charakteryzujące się potencjalnie wysoką atrakcyjnością inwestycyjną słabo zależną od działań władz lokalnych: dobrą dostępnością komunikacyjna, znacznymi zasobami nieruchomości nadającymi się potencjalnie dla inwestorów, dobrą dostępnością wykwalifikowanej siły roboczej. Wykluczono gminy, w których nawet bardzo intensywne zabiegi władz lokalnych nie dałyby zbyt wielu szans pozyskania nowych firm.

W badaniach starano się odpowiedzieć na pytanie, które elementy postawy władz lokalnych

- wskaźniki dobrego przywództwa, jak to definiują R. Hambelton i S. Bulloc (1996) - mają podstawowe znaczenie w procesie pozyskiwania inwestorów do gmin.

Do wskaźników tych zalicza się (Hambelton, Bulloc 1996, za: Swianiewicz i in. 2004):

- Określenie jasnej wizji dla terenu swojego działania - ustalenie, w jakim kierunku idziemy, i sformułowanie długoterminowych strategii i kierunków polityki; słuchanie w tym zakresie mieszkańców i przewodzenie inicjatywom.

- Promowanie specyficznych cech/właściwości swojego miejsca - budowanie dumy obywatelskiej, promowanie korzyści społeczności lokalnej i przyciaganie inwestorów.

- Zdobywanie nowych zasobów - poszerzenie zakresu kompetencji i źródeł finansowania z budżetu centralnego, maksymalizacja dochodów z różnych źródeł. 
- Rozwój partnerstwa - istnienie szerokich sieci współpracy z miastem, zarówno wewnętrznych, jak i zewnętrznych, współpracujących dla zaspokojenia potrzeb mieszkańców.

- Utrzymanie spójności i poparcia-zarządzanie podzielonymi interesami i utrzymywanie poparcia wyborców w celu zachowania autorytetu.

Tab. 1. Typy proinwestycyjnego nastawienia władz lokalnych badanych gmin

\begin{tabular}{|l|l|c|l|}
\hline \multicolumn{2}{|c|}{ Typ gminy } & $\begin{array}{c}\text { Liczba } \\
\text { przeprowadzonych } \\
\text { wywiadów }\end{array}$ & \multicolumn{1}{c|}{ Nazwa gminy } \\
\hline \multirow{2}{*}{ Metropolie } & 3 & Wrocław \\
\cline { 3 - 4 } & 4 & Kraków \\
\hline \multirow{2}{*}{$\begin{array}{l}\text { Gminy } \\
\text { proinwestycyjne }\end{array}$} & $\begin{array}{l}\text { doświadczone gminy } \\
\text { proinwestycyjne }\end{array}$ & 11 & $\begin{array}{l}\text { Niepołomice, Dobczyce, } \\
\text { Kobierzyce, Mielec }\end{array}$ \\
\cline { 2 - 4 } & $\begin{array}{l}\text { nowe gminy } \\
\text { proinwestycyjne }\end{array}$ & 10 & $\begin{array}{l}\text { Skawina, Tarnów, Myślenice, } \\
\text { Święta Katarzyna, } \\
\text { Kąty Wrocławskie }\end{array}$ \\
\hline \multicolumn{2}{|l|}{ Gminy nieinwestycyjne } & 6 & Kęty, Żórawina, Olkusz \\
\hline
\end{tabular}

Źródło: opracowanie autora

Celem tego opracowania jest próba odpowiedzi na pytanie o znaczenie i zróżnicowanie postaw władz lokalnych wobec działań proinwestycyjnych w gminach. Opisując zróżnicowanie stabilności władzy w różnych samorządach, autor postara się także odpowiedzieć na pytanie, czy (a jeśli tak - to jak często) zmiana władzy w gminie może być korzystna z punktu widzenia skuteczności działań proinwestycyjnych. Analizując przywództwo w gminach, badano wyniki działań wójtów, burmistrzów i prezydentów, wybranych przez rady gmin po pierwszych wyborach samorządowych 27.05.1990 r.

\section{Wizja proinwestycyjna}

Zgodnie z teorią planowania strategicznego gmin, rozwijaną często $\mathrm{w}$ ostatnich latach przez specjalistów w dziedzinie marketingu terytorialnego, ogólne cele (wizja) powinny być określane po zebraniu i przeanalizowaniu możliwie wielu informacji związanych z sytuacją i możliwościami rozwoju gminy (Kotler i in. 1999, Wells, Wint 2000, T. Domański 2002, Rainisto 2003). Działania proinwestycyjne w każdej z badanych gmin zaczynały się od wykreowania wizji. Cele ogólne - pozyskiwanie inwestycji - są wypracowywane już przed powstaniem odpowiednich dokumentów programowych. Najczęściej animatorzy nowych wizji proinwestycyjnych wywodzą się nielicznego grona osób zarządzających gminą. To władze lokalne są najczęściej głównymi promotorami działań proinwestycyjnych i niejako naturalnie obejmują przewodnictwo w koalicjach, tworzących się na rzecz pozyskania do gminy nowych firm.

Zidentyfikowano dwie przyczyny nieprowadzenia działań na skalę umożliwiającą pozyskanie nowych zewnętrznych przedsiębiorców. W niektórych gminach brak takich działań wynika z nieudolności i niekompetencji władz, które nie umieją zaplanować i realizować działań proinwestycyjnych. Z taką sytuacją można było się zetknąć w podwrocławskiej Żórawinie i w Olkuszu, a do początku 2003 r. także w Myślenicach. Żórawina wydaje się być przykładem szczególnie dobitnie wskazującym na zależność między jakością władz lokalnych a pozyskiwaniem nowych inwestorów. Jedynym elementem istotnie różniącym tę gminę od sąsiadujących z nią Kobierzyc i Świętej Katarzyny oraz nieodległych Kątów Wrocławskich, gmin mogących się pochwalić ogromnymi 
sukcesami w pozyskiwaniu nowych inwestorów, była po 1990 r. postawa władz lokalnych. W Żórawinie nie pojawił się odważny reformator z odpowiednią wizją który chciałby zmienić charakter gminy z rolniczego na przemysłowo-usługowo-rolniczy.

W innych gminach władze lokalne nie widzą potrzeby lub możliwości pozyskiwania inwestorów zewnętrznych, co niewątpliwie miało miejsce w Kętach. Władze lokalne, zainteresowane realizacją ważnych i dobrze postrzeganych przez lokalną społeczność zadań, związanych z rozwojem infrastruktury technicznej i społecznej, nie sformułowały jasnej strategii pozyskiwania inwestorów i nie wypracowały metod jej realizacji. W warunkach zaostrzającej się konkurencji o nowych inwestorów, brak przygotowanej i promowanej oferty praktycznie uniemożliwia pozyskanie nowych inwestorów. Kęty to miasto, w którym dobrze postrzegana przez lokalną społeczność władza nie wykreowała wizji pozyskiwania inwestorów, a co za tym idzie - nie wdrożyła praktycznie żadnych działań proinwestycyjnych mimo teoretycznie dość dogodnych warunków.

Najprawdopodobniej brak odpowiednich działań jest często wynikiem współwystępowania, w różnych proporcjach, obu przyczyn: nieudolności i braku zwerbalizowanej potrzeby, które sprowadzają się do braku wizji proinwestycyjnej. Jak wynika z badań klimatu inwestycyjnego w Małopolsce (Domański, Jarczewski 2006), znaczna większość władz lokalnych nie ma wizji pozyskiwania inwestorów, a więc nie wdraża działań proinwestycyjnych. Należy jednak pamiętać, że nie każda gmina ma wystarczające możliwości i nie każda potrzebuje nowych zewnętrznych inwestorów. Gminy proinwestycyjne charakteryzuje natomiast - w każdym ze zbadanych przypadków - obecność przywódcy potrafiącego sformułować wizję, która z czasem staje się programem dla podległych urzędników.

W dwóch badanych gminach - Dobczycach i Skawinie - udało się prześledzić skutki odejścia przywódców mających wizję proinwestycyjną i zastąpienia ich przez osoby nieumiejące patrzeć w taki sposób. W 1998 r. na 4 lata swoją gminę zostawił burmistrz Marcin Pawlak, a w Skawinie funkcję burmistrza przestał pełnić Jacek Krupa. Mimo że odchodzący szefowie gmin zostawiali różnego rodzaju opracowane dokumenty programowe, ich następcy przez kolejne 4 lata nie potrafili kontynuować dzieła. Takie sytuacje wskazują, że siła proinwestycyjna gmin tkwi nie w programach, lecz w lokalnych przywódcach.

W kilku badanych gminach można było zaobserwować wykreowanie polityki proinwestycyjnej w wyniku przejęcia władzy przez nowy zespół ludzi. W Kątach Wrocławskich, Świętej Katarzynie i Tarnowie do 1998 r. pozyskiwanie inwestorów nie było ważnym zadaniem. W tych 3 gminach na trzecią kadencję samorządową wybrano osoby, które jako cel wyznaczyły sobie pozyskanie nowych firm. W Tarnowie przez kilka lat mieszkańcy i politycy bezradnie przyglądali się, jak bardzo duże inwestycje lokowane są w nieodległym Mielcu, który jest gorzej położony pod względem komunikacyjnym. Wybrany w 1998 r. prezydent Józef Rojek, przy wsparciu swojego zastępcy i dzięki doświadczeniom uzyskanym podczas wyjazdów do Wielkiej Brytanii, wskazał urzędnikom cel - pozyskiwanie inwestorów, który stopniowo zaczął być realizowany. Jego zamierzenia realizował wybrany w 2002 r. prezydent Mieczysław Bień, który sprawował już funkcję prezydenta w latach 90. Postawa tego prezydenta w latach sprawowania władzy wskazuje, że do zmiany polityki proinwestycyjnej nie zawsze jest konieczna zmiana władz lokalnych. Przywódcy, którzy w pierwszych latach rządzenia skupiali się na rozwiązywaniu podstawowych problemów społeczności lokalnej, z czasem mogą ewoluować w kierunku szerzej pojmowanego przywództwa, nastawionego na animowanie lokalnego rozwoju.

Kąty Wrocławskie i Święta Katarzyna, z powodu doskonałego położenia, po przygotowaniu atrakcyjnych ofert bardzo szybko zaczęły pozyskiwać inwestorów. Mając wizję proinwestycyjną i doskonałe położenie, te gminy przez wiele następnych lat będą miejscem lokalizacji nowych 
przedsiębiorstw. O tym, jak ważne jest podjęcie próby wykorzystania swoich atutów, świadczyć może przykład Myślenic, gdzie niestabilny samorząd przez 13 lat nie potrafił otworzyć gminy na inwestorów. Młody i ambitny burmistrz Maciej Ostrowski, który objął władzę w 2003 r., w ciagu kliku miesięcy przekonał urzędników do swojej wizji i po 2 latach pozyskał pierwszego poważnego inwestora. Gminy, które obecnie oceniane są jako liderzy w pozyskiwaniu inwestorów na skalę Polski czy poszczególnych regionów, prowadzą skuteczną politykę proinwestycyjną od pierwszej połowy lat 90 . XX w.

Spośród badanych gmin wiejskich i małych miast - niemal od samego początku transformacji ustrojowej - cel w postaci pozyskania nowych inwestycji niewątpliwie miały władze Niepołomic, Kobierzyc i Dobczyc. W każdej z tych gmin bardzo wąskie grono lokalnych przywódców już na początku lat 90. dostrzegło szansę gminy tam, gdzie inni jej nie widzieli. Przykładem gminy, w której sukces w postaci wielu nowych inwestycji był wynikiem działań prowadzonych od połowy lat 90 ., jest także Mielec, choć w tym przypadku znaczenie władz lokalnych było stosunkowo niewielkie.

\section{Metropolie}

W dużych miastach (metropoliach), takich jak Kraków i Wrocław, znacznie trudniej wiązać działania władz lokalnych z decyzjami lokalizacyjnymi inwestorów. Na scenie miejskiej istotne znacznie ma duża liczba silnych podmiotów, które są w stanie realizować różnego rodzaju cele bez wsparcia, a nawet mimo sprzeciwu władz i lokalnych społeczności. Niektórzy inwestorzy są zdeterminowani na lokalizację w dużym mieście i pozytywne lub negatywne działania nie mają większego wpływu na tę decyzję. W. Dziemianowicz i B. Jałowiecki (2004) uważają, że ,wielki potencjał, skupiony w metropoliach, staje się głównym czynnikiem lokalizacji”. Taką postawę przyjmują często firmy usługowe, a także niektóre firmy zajmujące się wyspecjalizowaną produkcja, w szczególności korporacje międzynarodowe. Kierują się przede wszystkim ku największym ośrodkom miejskim, gdzie mogą stosunkowo łatwo znaleźć odpowiednią siłę roboczą, usługi dla biznesu, dogodne połączenia komunikacyjne, potencjał badawczy i odpowiednie warunki życia.

W przebadanej grupie 10 średnich firm, zajmujących się szeroko pojętymi usługami informatycznymi, które w Krakowie ulokowały się po 1990 r., działania władz lokalnych ani razu nie zostały wymienione wśród czynników istotnych przy podejmowaniu decyzji lokalizacyjnych. Działania władz lokalnych miały natomiast pewne znaczenie dla dużych międzynarodowych koncernów działających w sektorze usług, jak Motorola w Krakowie czy HP we Wrocławiu, szczególnie na etapie budowy lub przebudowy nieruchomości. Bardzo trudno jednak wyrokować o wpływie podejmowanych działań na decyzje lokalizacyjne. W ocenie przedstawicieli Motoroli - władze Krakowa nie ułatwiały procesu inwestycyjnego, a inwestycja powstała pomimo wielu problemów wynikających z braku profesjonalnej obsługi. Motorola chciała zainwestować w Krakowie i zrobiła to. Brak wsparcia ze strony władz Krakowa opóźnił rozpoczęcie działania firmy. Przedstawicielka innej dużej firmy, zajmującej się księgowością Airline Accounting Center Lufthansa - Hedwig E. Hardtke, wypowiadając się na temat procesu lokalizacyjnego, oceniła, że „nikt z władz miasta nie był zainteresowany planami naszego centrum BPO na 150 pracowników. Nie uzyskaliśmy pomocy nawet w znalezieniu powierzchni biurowej" (Polska-centrum ustug... 2003). Bardzo pozytywnie jest natomiast oceniane przez HP zaangażowanie władz Wrocławia w pomoc związaną z utworzeniem centrum usługowego. Dzięki wsparciu udało się tej firmie w ciągu kilku miesięcy rozpocząć działalność.

W badanych metropoliach różne style sprawowania władzy wywołują różnego rodzaju komentarze wśród inwestorów, którzy zdecydowali się na lokalizację w danym mieście, i tych, którzy wybrali inne miejsca. Wyniki, w postaci napływu nowych inwestycji zewnętrznych, nie wydają się 
jednak być bezpośrednio związane z działaniami władz lokalnych. Mimo nienajlepszej opinii, w Krakowie ciagle lokują się nowi inwestorzy. Można postawić tezę, wymagającą dalszych badań, że szczególnie profesjonalne prowadzenie działań proinwestycyjnych może w metropoliach wzmocnić napływ inwestorów w dłuższym okresie, a szczególnie złe - spowolnić ten proces.

\section{Stabilność władzy}

Oprócz wizji proinwestycyjnej i umiejętności (zdolności) jej realizacji - ważnym elementem wpływającym na skuteczność działań proinwestycyjnych jest stabilność władzy. Częstość zmian na stanowisku szefa gminy jest oceniana jako jeden z najważniejszych czynników wpływających na stabilność polityki lokalnej. Niewątpliwie zbyt częste zmiany uniemożliwiają prowadzenie skutecznej polityki, w tym proinwestycyjnej (Swianiewicz, Klimska 2003a, 2003b). Pojawia się jednak pytanie, kiedy zmiany są zbyt częste i czy zmiany na stanowisku prezydentów, wójtów i burmistrzów są jako takie, czymś zawsze niekorzystnym dla lokalnych społeczności.

\section{Liczba kadencji a dzialania proinwestycyjne}

Szefowie gmin, w których przeprowadzano badania, podkreślają, że jedna kadencja to stanowczo zbyt mało, żeby wymyślić, zaplanować i zrealizować działania sprzyjające pozyskaniu inwestorów. Opinie takie wyrażają zarówno osoby zarządzające gminami więcej niż jedną kadencję (Niepołomice, Kobierzyce, Dobczyce, Święta Katarzyna, Tarnów), jak i ci, którzy swój urząd sprawują od początku obecnej kadencji - od 2002 r. (Wrocław, Kraków), a nawet krócej (Myślenice, Żórawina). Jak wskazuje przykład Skawiny, burmistrz mający jasną wizję i starający się ją energicznie realizować w trakcie jednej kadencji może nie zdążyć nawet przygotować oferty, nie mówiąc już o jej promocji i pozyskaniu inwestora. W trakcie jednej kadencji w najlepszym przypadku udaje się pozyskać jednego lub dwóch inwestorów (Myślenice, Święta Katarzyna).

Zdaniem szefów badanych gmin, osoba obejmująca urząd prezydenta, burmistrza czy wójta przez pierwszy rok poznaje swoje obowiązki i uczy się zasad zarządzania gminą. Jeżeli nie ma wcześniejszych doświadczeń na tym stanowisku, to dopiero w drugim roku urzędowania jest w stanie rozpocząć systematyczne programowanie i wdrażanie działań prorozwojowych, $w$ tym proinwestycyjnych. Nieco krócej trwa ten proces w przypadku osób pełniących wcześniej funkcje zastępców szefa gminy lub członków zarządu. Czwarty rok każdej kadencji jest okresem wyborczym, co w znacznym stopniu ogranicza możliwość podejmowania decyzji trudnych i niepopularnych, a często koniecznych, szczególnie w procesie przygotowywania ofert inwestycyjnych.

Pozyskiwanie inwestorów to proces rozpisany na wiele lat. Przygotowanie działki zaczyna się od sporządzenia planu zagospodarowania, następnie należy ustalić stan własności, czasami wykupić nieruchomość i przynajmniej częściowo ją uzbroić, doprowadzić drogę dojazdową itd. Po przygotowaniu oferty rozpoczyna się jej promocja, a następnie negocjacje z potencjalnymi inwestorami, a w przypadku decyzji lokalizacyjnej - wsparcie podczas procesu inwestycyjnego. Za minimalny okres umożliwiający podjęcie działań i ocenę efektów uważa się w badanych gminach 8 lat, czyli 2 kadencje. Władze Tarnowa rozpoczęły działania proinwestycyjne w 1998 r.; 2 lata trwały prace koncepcyjne i uchwalanie odpowiedniego planu zagospodarowania terenu. Na początki $2006 \mathrm{r}$. w tym mieście rozpoczął się ósmy rok aktywnego pozyskiwania inwestorów i ciaggle był to, zdaniem jednego z urzędników - ,początek drogi”. Dynamiczny rozwój strefy inwestycyjnej i napływ nowych inwestorów w Świętej Katarzynie rozpoczął się w połowie drugiej kadencji wójta. Także w Kątach Wrocławskich dopiero druga kadencja burmistrza pozwoliła na realizację wizji sformułowanej podczas pierwszych 4 lat rządzenia. 
Należy się jednak zastanowić, czy każda kolejna kadencja - trzecia, czwarta - pozwala na coraz lepsze wdrażanie działań proinwestycyjnych. Na przykładzie przebadanych gmin można powiedzieć, że w niektórych przypadkach kolejne kadencje przynoszą coraz większe sukcesy. Taką gminą są Niepołomice. Burmistrz - mający jasną wizję i umiejący ją systematycznie wdrażać - największy sukces, jakim było pozyskanie fabryki ciężarówek MAN Trucks, odniósł w trakcie swojej czwartej kadencji.

Długie utrzymywanie władzy w gminie przez te same osoby nie musi być zawsze korzystne dla lokalnych społeczności. Osoby, sprawujące władzę i dążące do realizacji różnych celów, zmuszone są do wchodzenia w koalicje $\mathrm{z}$ różnego rodzaju graczami sceny lokalnej i ponadlokalnej. Umiejętność współpracy z różnymi partnerami i zawiązywania koalicji jest szczególnąi zazwyczaj pozytywnie ocenianą cechą skutecznych władz lokalnych (por. Sagan 2000). Długie trwanie w lokalnych układach, a także sukcesy odnoszone na arenie gminnej i brak możliwości legalnego zwiększenia dochodów z powodu ograniczeń ustawowych mogą w niektórych przypadkach skłaniać przedstawicieli władz lokalnych do zachowań niezgodnych z prawem. Burmistrz Dobczyc i pierwszy wójt Kobierzyc to przykłady osób, które pomogły swoim gminom w osiągnięciu niezwykłych sukcesów w pozyskiwaniu inwestorów i które w trakcie trzeciej kadencji zostały oskarżone o korupcję. Oskarżeń o niegospodarność nie uniknął także burmistrz Niepołomic.

Innym problemem niektórych osób długo sprawujących urząd (ponad dwie kadencje) jest brak możliwości dalszego rozwoju. Szefowie gmin obejmują stanowisko często jako ludzie stosunkowo młodzi: trzydziesto-, czterdziestoletni. Po dwóch, trzech kadencjach dostrzegają, że w gminie osiagnęli już wszystko i nie ma przed nimi dalszych możliwości awansu. Zarządzanie gminą realizowane jest według wypracowanych przez lata schematów i z czasem zaczyna im brakować świeżości. W niektórych przypadkach szefowie gmin rezygnują ze starania się o kolejną kadencję i próbują znaleźć swoje miejsce np. w innych organach samorządu terytorialnego, w sejmie, senacie. Prezydentami odnoszącymi sukcesy w zarządzaniu gminą, także w działaniach proinwestycyjnych, i dobrowolnie rezygnującymi z niemal pewnej kolejnej kadencji, byli Bogdan Zdrojewski we Wrocławiu w 2002 r. i Marcin Pawlak w Dobczycach w 1998 r. Swoich sił w parlamencie próbował także Stanisław Kracik z Niepołomic, ale stając przed wyborem: sejm czy gmina - wybrał gminę. Ta decyzja jest obrazem poważniejszego dylematu, przed którym stają szefowie gmin szukający innego miejsca w życiu. Burmistrz jednej z badanych gmin stwierdzil, że „,porównywalną samodzielność i możliwość realizacji swoich wizji, większy prestiż i wyższe zarobki dają dobrym i lubianym szefom gmin tylko bardzo nieliczne stanowiska w administracji samorządowej i rządowej, takie jak marszałek województwa, wojewoda, starosta, minister w rządzie, marszałek w sejmie i senacie". Z podobnymi opiniami podczas prowadzonych badań spotykano się częściej. Okazuje się, że samo bycie posłem czy senatorem, a nawet wiceministrem, wicemarszałkiem lub wicestarosta, jest postrzegane jako rodzaj degradacji przez wielu dobrych szefów gmin, choć oczywiście nie przez wszystkich. Długoletni burmistrz Skawiny Jacek Krupa został starostą powiatu krakowskiego, a od 2005 r. jest posłem i nie podejmuje prób powrotu do Skawiny. Nie jest jednak przypadkiem, że Stanisław Kracik wybrał niewielką gminę miejsko-wiejska, a nie fotel posła, ani że Marcin Pawlak zrezygnował z sejmiku wojewódzkiego na rzecz malutkich Dobczyc.

\section{Przejęcie władzy w gminie}

Na podstawie przeanalizowanych przypadków można stwierdzić, że wymyślenie, zaplanowanie i rozpoczęcie realizacji działań proinwestycyjnych oraz pozyskanie pierwszych inwestorów wymaga zasadniczo dwóch kadencji (8 lat). Jeżeli szef gminy chciał pozyskiwać inwestorów od pierwszych lat swojego urzędowania i było to poparte obiektywnymi możliwościami zewnętrz- 
nymi, to trzecia kadencja działań proinwestycyjnych powinna przynosić liczne sukcesy w postaci napływu wielu nowych firm. Najczęściej w którymś momencie nawet bardzo dobrze prowadzonych działań proinwestycyjnych przychodzi jednak potrzeba zmiany władz lokalnych z szefem gminy na czele. Przyczyny zmiany na tym stanowisku mogą mieć dwojaką naturę:

- zewnętrzną, wynikającą z utraty poparcia lokalnej społeczności lub/i wejścia w konflikt z prawem;

- wewnętrzną, wynikającą z chęci zmiany miejsca pracy przez lokalnego przywódcę.

Wpływ zmian na stanowisku szefa gminy na działania proinwestycyjne może być pozytywny lub negatywny, ale każdorazowo jest trudny do przewidzenia. W gminach, w których nie prowadzi się działań proinwestycyjnych, każda zmiana to nowa szansa. W Myślenicach dopiero szósty burmistrz otworzył miasto dla inwestorów. W Kątach Wrocławskich i Świętej Katarzynie osoby, które przejęły władzę w 1998 r., potrafiły stworzyć warunki do lokowania nowych przedsiębiorstw. W Skawinie burmistrz rządzący od 2002 r. próbuje znowu włączyć swoją gminę na listę atrakcyjnych inwestycyjnie miejsc w Małopolsce. Wiele, a być może nawet większość gmin wciąż czeka na przywódcę potrafiącego stworzyć alternatywę dla dotychczasowego kierunku rozwoju. Mimo wielokrotnych zmian na stanowisku szefa gminy, nie rozpoczęto prowadzenia intensywnych działań proinwestycyjnych w Olkuszu.

Zmiana szefa gminy, który skutecznie prowadził działania proinwestycyjne, może spowolnić, a nawet zatrzymać na pewien czas napływ nowych przedsiębiorców. Rezygnacja burmistrza Dobczyc w 1998 r. praktycznie o całą kadencję spowolniła rozwój strefy inwestycyjnej. Burmistrz Skawiny Stanisław Pac nie wykorzystał sukcesu, jakim było pozyskanie fabryki Valeo przez poprzednika, i nie kontynuował działań proinwestycyjnych podczas swojej kadencji w latach 1998-2002.

W niektórych gminach zmiana władzy nie tylko nie zatrzymuje procesu proinwestycyjnego, ale wręcz go przyspiesza, $i$ to zarówno w przypadku przejęcia władzy przez oponenta politycznego, jak i przez kandydata popieranego przez osobę ustępującą ze stanowiska. Przykładu przejęcia władzy przez oponenta politycznego dostarczają Kobierzyce. Wójt Ryszard Chomicz, po dekadzie niezwykle skutecznych działań, został odwołany w atmosferze skandalu. Na czele jego oponentów, którzy doprowadzili do dymisji, stał Ryszard Pacholik. Po przejęciu urzędu potrafił twórczo rozwinąć koncepcje swojego poprzednika, a pozyskanie koncernu LG przywróciło Kobierzycom sławę jednej z najlepszych proinwestycyjnie gmin w Polsce. Poparcie ustępującego prezydenta miały obie osoby rządzące Wrocławiem od 2002 r. Skutecznie zarządzający miastem, w tym działaniami proinwestycyjnymi, bardzo popularny prezydent Bogdan Zdrojewski postanowił zrezygnować z ubiegania się o kolejną kadencję w 2002 r. Poparł swego następcę Rafała Dutkiewicza, który wygrał wybory bezpośrednie i kontynuuje, a czasem modyfikuje rozpoczęte wcześniej działania, dostosowując je do zmieniającego się otoczenia.

\section{Wnioski}

Cechą charakterystyczną tych spośród badanych gmin, które odniosły sukces w pozyskiwaniu inwestorów, był silny lider lub - rzadziej - zespół dysponujący wizją rozwoju oraz umiejętnością wdrażania jej w życie za pomocą różnego rodzaju narzędzi. Niektóre samorządy przez wiele lat pozyskiwały niewielu nowych inwestorów lub w ogóle nie próbowały ich pozyskać, a po zmianie władz zaczęły odnosić sukcesy. Można także zaobserwować zależność odwrotną. Gminy, w których - mimo teoretycznie dobrych warunków zewnętrznych - nie lokują się inwestorzy, mają władze nieumiejące ich pozyskać lub niezainteresowane ich pozyskiwaniem.

W ramach badań starano się odpowiedzieć na pytanie, które elementy postawy władz lokalnych - wskaźniki dobrego przywództwa, jak to definiują R. Hambelton i S. Bulloc (1996) - mają 
kluczowe znaczenie w procesie pozyskiwania inwestorów do gmin. W każdej spośród badanych małych i średnich gmin, które skutecznie pozyskują nowe firmy, istnieje wizja działań proinwestycyjnych. Chęć pozyskania inwestorów oraz generalny pomysł, jak można to w warunkach lokalnych zorganizować, okazuje się fundamentem i napędem dalszych działań. Brakującą wiedzę (know-how) można uzupełnić, zbierając informacje od gmin bardziej doświadczonych i zatrudniając odpowiednich specjalistów, co doradzają konsultanci PAIiIZ. Różnego rodzaju szkolenia urządzają przedstawiciele PAIiIZ, urzędów marszałkowskich i regionalnych agencji rozwoju. Środki konieczne do przygotowania atrakcyjnej oferty, promocji i obsługi inwestorów można w miarę możliwości corocznie przydzielać $\mathrm{z}$ budżetu lub też pozyskiwać z funduszy pomocowych. Jak wykazują doświadczenia badanych gmin, jedynym elementem, który musi zostać wypracowany w gminie i którego nie da się w żaden sposób zastąpić ani ,importować” z zewnątrz, jest wizja i chęć jej wdrażania przez władze lokalne, a szczególnie przez szefa gminy. W wielu gminach, szczególnie małych i średnich, można zauważyć ścisłą zależność między pojawieniem się wizji proinwestycyjnej i rozpoczęciem jej realizacji a decyzjami lokalizacyjnymi nowych inwestorów. W gminach, które teoretycznie mają doskonałe warunki do pozyskiwania nowych firm, a w których nie prowadzi się działań proinwestycyjnych, nowi przedsiębiorcy lokują się rzadko (Domański, Jarczewski 2006).

W metropoliach, takich jak Kraków czy Wrocław, decyzje lokalizacyjne nowych inwestorów zewnętrznych wydają się słabiej związane z aktywnością władz gminnych. Duże miasta, jak pisze B. Jałowiecki (1999), są w pewien sposób dobrem rzadkim i przyciągają inwestorów bez względu na działania i postawę władz lokalnych. Badając relacje pomiędzy nowymi inwestorami, którzy lokowali się w Krakowie i Wrocławiu, a miejscowymi władzami lokalnymi, sformułowano następujące wnioski.

- Niektórzy lokalizujący się w dużych miastach inwestorzy nie potrzebują zbyt wielu kontaktów z władzami lokalnymi (np. firmy zajmujące się usługami, wynajmujące powierzchnię biurową).

- Firmy lokalizują się w metropoliach głównie ze względu na pewne szczególnie atrakcyjne dla nich cechy (np. wykształconą siłę robocza, rynek zbytu) i zdecydowane są na rozpoczęcie działalności w danym mieście nawet jeżeli będzie to trwało dłużej i kosztowało więcej niż gdzie indziej. W dłuższej perspektywie prawdopodobnie proinwestycyjna postawa władz lokalnych będzie miała istotne znaczenie, zwłaszcza jeżeli utrwalą się zróżnicowane postawy względem inwestorów.

W. Dziemianowicz i B. Jałowiecki (2004) zwracają uwagę na znaczenie ciągłości władzy w procesie pozyskiwania nowych inwestorów. Przeprowadzone przez autora badania wskazały, że utrzymanie poparcia wyborców, pozwalającego na pełnienie funkcji przez więcej niż jedną kadencję, jest warunkiem prowadzenia skutecznych działań proinwestycyjnych. W gminach, w których wielokrotnie zmieniali się szefowie, działania proinwestycyjne są zazwyczaj słabo zaawansowane lub nie ma ich wcale. Każda kolejna zmiana jest jednak także szansą na rozpoczęcie takich działań. Minimalnym okresem umożliwiającym sformułowanie wizji, przygotowanie atrakcyjnej oferty i jej promocję, a następnie doprowadzenie do zlokalizowania w gminie nowych inwestorów, są dwie kadencje - 8 lat. Kolejne kadencje, dzięki wypracowaniu odpowiednich procedur, pozwalają na skupienie wysiłków na działaniach mogących przynosić najlepsze rezultaty. W niektórych przypadkach zbyt długie pełnienie funkcji przez te same osoby jest jednak przyczyną utraty świeżości i energii działań proinwestycyjnych, a może nawet powodować uwikłanie się szefa gminy w działania niezgodne z prawem. W niektórych przypadkach zmiana na stanowisku szefa gminy powoduje znaczne spowolnienie, a nawet zaprzestanie prowadzenia działań proinwestycyjnych. Zdarzają się także gminy, w których zmiana na stanowisku wójta, 
burmistrza czy prezydenta nie tylko nie utrudnia napływu nowych inwestorów, ale wręcz go przyspiesza. Może się tak dziać zarówno w przypadku wyznaczenia następcy przez ustępującego szefa gminy, jak i przejęcia władzy przez jego oponentów politycznych. Ciagłość władzy nie jest równoznaczna z ciagłością działań proinwestycyjnych.

\section{Literatura}

1. Domański T., 2002, Skuteczna promocja miasta i regionu podstawowym zadaniem marketingu terytorialnego [w:] T. Markowski (red.), Marketing terytorialny, Studia Komitetu Przestrzennego Zagospodarowania Kraju PAN, T. CXII,. Warszawa

2. Dziemianowicz W., Jałowiecki B., 2004, Polityka miejska a inwestycje zagraniczne w polskich metropoliach, Scholar, Warszawa

3. Hambelton R., Bulloc S., 1996, Revitalizing local democracy - the leadership options, Association of District Councils/Local Government Management Bard, London

4. Jałowiecki B., 1999, Metropolie, Wyższa Szkoła Finansów i Zarządzania w Białymstoku, Białystok

5. Klimat inwestycyjny w województwie małopolskim, 2006, B. Domański, W. Jarczewski (red), Urząd Marszałkowski Województwa Małopolskiego, Kraków

6. Kotler P., Asplund C., Rein I., Haider D., 1999, Marketing places Europe, Pearson Education Ltd., London

7. Osborne D., Gaebler T., 1995, Rzq̨dzić inaczej. Jak duch przedsiębiorczości przenika i przeksztatca administracje publicznq, Media Rodzina of Poznań, Poznań

8. Polska - centrum ustug dla Europy. Nowe szanse inwestycji zagranicznych w Polsce, 2003, McKinsley\&Company/Polska Rada Biznesu, Warszawa

9. Rainisto S., 2003, Success factors of place marketing: a study of place marketing practices in northern Europe and the United States, University of Technology, Helsinki

10. Sagan I., 2000, Miasto scena konfliktów i wspótpracy: rozwój miasta w świetle koncepcji reżimu miejskiego, Wydawnictwo Uniwersytetu Gdańskiego, Gdańsk

11. Swianiewicz P., Klimska U., 2003a, Czy wielkie miasta sq sterowalne? Wpływ sytuacji politycznej na warunki zarzadzania największymi miastami Polski, „Samorząd Terytorialny” 3/2003

12. Swianiewicz P., Klimska U., 2003b, Kto rzqdzi gminq i jak? Lokalni liderzy polityczni w teorii i praktyce samorzadów w Polsce, ,Studia Regionalne i Lokalne” 4 (14), 15-41/2003

13. Swianiewicz P., Łukomska J., 2004, Władze samorzqdowe wobec lokalnego rozwoju gospodarczego. Które polityki sq skuteczne? „Samorząd Terytorialny” 6, 14-32/2004

14. Wells L., Wint A., 2000, Marketing a country: promotion as a tool for attracting foreign investment, FIAS, Washington 


\section{The Spirit of Entrepreneurship in Pro-investment Activities of Municipalities}

The acquisition of new investors in a municipality is not a direct obligation of local governments but rather one of the indications of the change in the philosophy of municipal management - from administration (local government) to management (local governance). Time and cost consuming comprehensive pro-investment activities can be implemented only in those municipalities where among the local authorities the spirit of entrepreneurship is alive. G. Gorzelak (1998) indicated that on the local level the leadership quality is the most endogenic factor of local success, including luring new investors.

To examine the significance and diversity of local authorities' attitudes in their pro-investment activities in the local governments, in fourteen selected municipalities in Poland a comparative analysis was conducted. Pro-investment activities, implemented since 1990, and their effects, in the form of arrival of new investors, were studied. Our research covered the municipalities distinguished by potentially high investment attractiveness which is hardly dependent on the local authorities' activities: good transportation availability, considerable real-estate resources that are suitable for potential investors and good availability of qualified labor force. Consequently, we excluded the municipalities in which even very intense works of their local authorities failed to develop new opportunities to attract many new businesses. 